\title{
DRIP-IRRIGATION EFFECTS ON SALT MOVEMENT IN SOIL AT SIWA OASIS
}

\author{
Awady $^{1}$, M. N., M. A. Wassif ${ }^{2}$, M. F. Abd el-Salam ${ }^{3}$, and M. A. El-Farrah ${ }^{4}$
}

\section{ABSTRACT}

The aim of this investigation is to evaluate the behavior of salt concentration distribution under surface and subsurface drip irrigation technique in Siwa Oasis hyper arid condition with using low quality water. The experimental results showed that salt moving from surface to the root zone in Adjacent Lines (AL) was more than Vertically Spaced Lines (VSL) and increasing dripline depth decreased the accumulated salt. In case of without Poly-ethylene (PE) foil, the best WUE for onion reached $0.5 \mathrm{~kg} / \mathrm{m}^{3}$ in the case of VSL with $0.8-1.0 \mathrm{~m}$ spacing and $10 \mathrm{~cm}$ depth and the highest onion $(2.42 \mathrm{t} / \mathrm{fed})$ yield under VSL arrangement was obtained from $10 \mathrm{~cm}$ dripline depth and dripline spacing range $0.4-$ $0.6 \mathrm{~m}$. In case with PE foil, the highest onion yield under VSL arrangement $(2.9 \mathrm{t} / \mathrm{fed})$ was obtained from $25 \mathrm{~cm}$ dripline depth and dripline spacing range $0.3-0.6 \mathrm{~m}$.

Keywords: Drip irrigation, Subsurface drip, Underneath PE foil, Saline water, Siwa Oasis, and Onion.

\section{INTRODUCTION}

W ith human development and limitation in water resources, new technologies are found. In Siwa Oasis, there is a lot of drainage saline water. Recent techniques can use this low quality water in safe and beneficial gains.

The use of saline water for agricultural irrigation is attractive for the following reasons: a) Water shortage problems can be resolved; b) Large amounts of saline water can be disposed of during the entire year, with minimal risk of groundwater deterioration; c) Economic benefits of higher market price for the fruits, which are sweeter with extended shelf life, due to the stressful growing conditions (Oron et al., 1995). Under arid and semi-arid conditions associated high solar radiation, intensive evaporation from the soil surface takes place.

(1) and (3) resp. Prof. Emerit. and Assoc. Prof., Ag. Eng. Dep., A. Shams U., Cairo, Misr (Egypt).

(2) and (4) resp. Prof.. Emerit. and Res., Soil Conserv. Dep., Desert Res. Center., Cairo, Misr (Egypt). 
Therefore salt could accumulate in the root zone if leaching is not maintained, resulting in poor yields. It is anticipated that under subsurface drip-irrigation, the evaporation will be minimized and the salt front will be positioned below the root zone and risk of damaging the plants is minimized. Since the water does not reach the soil surface, the surface remains dry; thus minimizing the saline water effect, (Keller and Karmeli, 1975). Accordingly, best results were obtained with emitters located at a depth of $30 \mathrm{~cm}$, when pear orchard was taken as indicator, (Oron, et al., 1995). The aim of this investigation is to evaluate the behavior of salt concentration distribution under surface and subsurface drip irrigation technique in Siwa Oasis hyper arid condition with using low quality water.

\section{MATERIALS AND METHODS}

\section{Site of the experiment:}

Two field experiments were conducted during winter season (2006 - 2007) in Agricultural Experiment Station of the Desert Research Center (DRC), Siwa oasis - Mersa Matruh Governorate. Siwa depression is located on the northern edge of the great sand sea, one of the largest sand areas in the world in the western desert of Egypt at about $750 \mathrm{~km}$ north west of Cairo and $300 \mathrm{~km}$ west south Mersa Matruh (The Mediterranean coast). Depression has a length of about $75 \mathrm{~km}$ and a width varying between 5 and $25 \mathrm{~km}$ with a total area of about $1088 \mathrm{~km}^{2}$. The elevation of the floor is 0 to $-18 \mathrm{~m}$ from sea level and the longitude ranges between $25^{\circ} 18^{\prime}-26^{\circ}$ $\mathrm{E}$ and the latitude ranges between N. $29^{\circ} 5^{\prime}-29^{\circ} 20^{\prime}$

The soil of experiments is deeply sand. It is a part of sand dune, which is very deep and the water table surface is about $4 \mathrm{~m}$ depth.

To determine soil properties of experimental site, individual samples ( 0 $60 \mathrm{~cm}$ ) were collected. The soil samples were dried, sieved through 2 $\mathrm{mm}$ sieve, then mixed to composite soil sample to represent the experimental site and reserved for soil analysis. The representative soil sample was subjected to the following methods in DRC laboratories.

a. Particle-size distribution was measured by dry sieving, according to Gee and Bauder (1986).

b. Electrical conductivity (ECe) in the soil paste extract was measured by using measuring device according to Richards (1965). 
c. Soil pH in the soil paste was measured using $\mathrm{pH}$ electrode device according to Peech (1965).

d. Bulk density $\left(\rho_{b}\right)$ was obtained by dividing samples weight per volume according to Blake and Hartge (1986).

Field capacity and wilting point ( $\mathrm{V} \%)$, were determine using pressure cooker and pressure membrane, respectively.

Some physical and chemical properties of soil sample of the soil experimental site are shown in Tables (1).

Table (1): Some physical and chemical properties of the experimental soil site.

\begin{tabular}{|c|c|c|}
\hline Particle size (\%) & Very Coarse sand & 0.15 \\
\cline { 2 - 3 } & Coarse sand & 11.67 \\
\cline { 2 - 3 } & Medium Sand & 29.86 \\
\cline { 2 - 3 } & Fine sand & 46.68 \\
\cline { 2 - 3 } & Very Fine Sand & 10.81 \\
\hline Silt + Clay & 0.85 \\
\hline Textural class & Sand \\
\hline Bulk density (g/cm $\left.{ }^{3}\right)$ & 1.66 \\
\hline Field capacity (V \%) & 16.2 \\
\hline Permanent wilting point (V \%) & 7.6 \\
\hline Available water (V \%) & 8.6 \\
\hline pH & 7.73 \\
\hline EC (dS.m $\left.{ }^{-1}\right)$ & 7.40 \\
\hline Saturated hydraulic conductivity (mm/min) & 8.03 \\
\hline
\end{tabular}

\section{Irrigation system installation and experimental treatments:}

The first experiment $\left(\mathbf{E}_{1}\right)$ without $\mathrm{PE}$ foil was carried out including the following treatments:

a. Two Adjacent Lines (AL) and two Vertically-Spaced Line (VSL) at 15 $\mathrm{cm}$ in-between.

b. Variation in driplines depth ((upper dripline of VSL or AL depth was 0 and $10 \mathrm{~cm}$ ).

c. Variation in the driplines spacing (0.4 to $1.0 \mathrm{~m}$ ).

The main treatment was the driplines arrangement (AL or VSL). Submain treatments were the dripline depth $(\mathrm{D}=0$ or $10 \mathrm{~cm})$ and, variation of dripline spacing ( $\mathrm{S}$ from 0.4 to $1.0 \mathrm{~m}$ ), as shown in Fig. (1). 


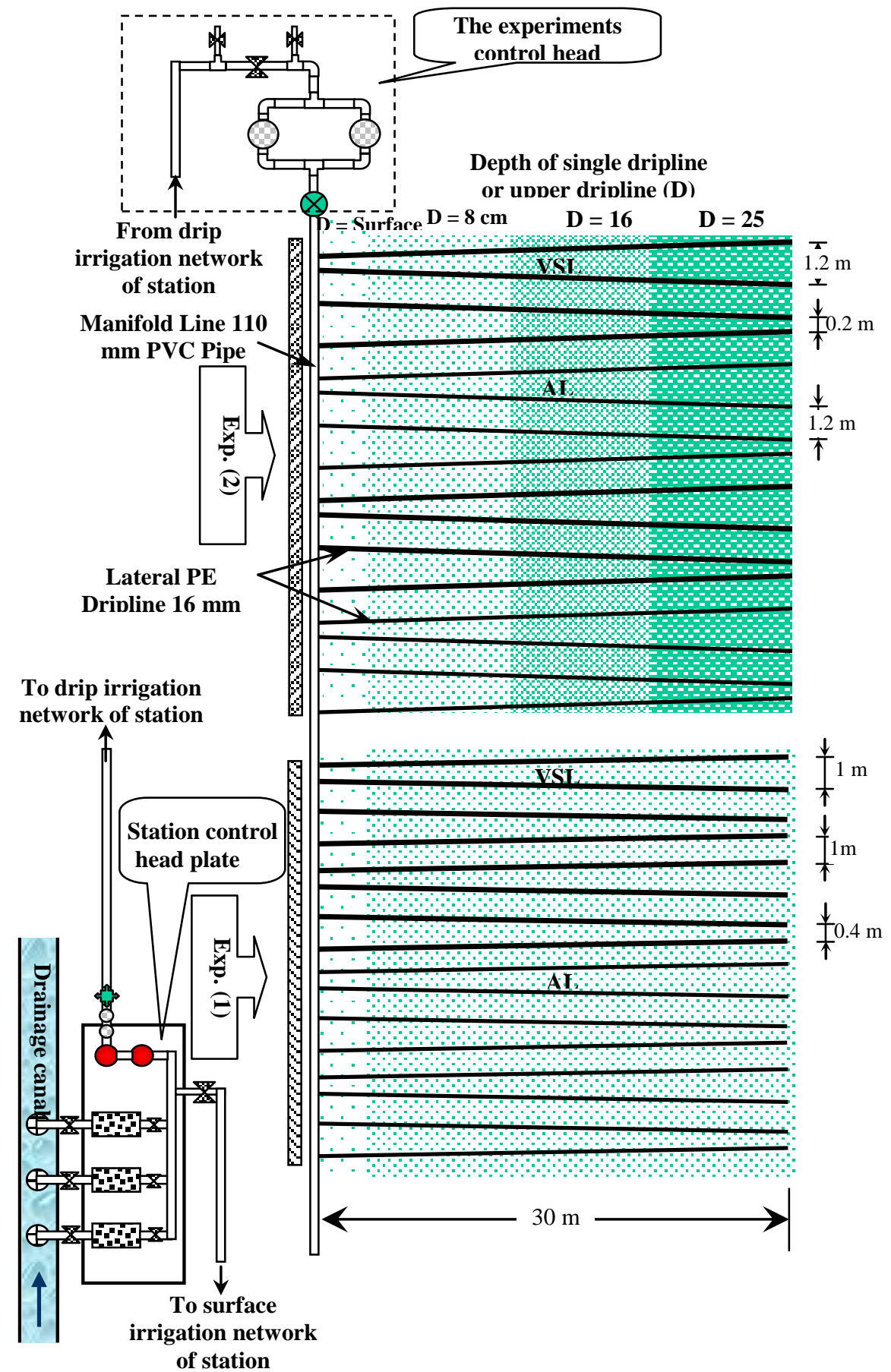

Fig. (1): Layout sketch of irrigation system (With variable lateral spacings as advised by El Awady). 
It is worth to mention that using $15 \mathrm{~cm}$ Vertically-Spaced driplines in VSL conforms to Ismail et al. (2006).

The second experiment $\left(\mathbf{E}_{2}\right)$ had underneath PE foil, with the following treatments:

a- Dripline arrangement (AL and VSL).

b- Variation in driplines depth (upper dripline in VSL or AL depth was varied from 0 to $25 \mathrm{~cm}$ ).

c- Variation of the driplines spacing (0.2 to $1.2 \mathrm{~m})$.

Onion seedlings (Yellow creol, Allium cepa) were sown on 3/1/2007. The crop yield was obtained and recorded for each treatment.

The statistical analysis methods used are fully described by El-Roby (1991). Irrigation water use efficiency (WUE) is defined as the "yield/cu.m. of water" ratio according to, Burman et al. (1983).

\section{RESULTS AND DISCUSSIONS}

\section{Soil salt distribution of treatment without underneath foil $\left(E_{1}\right)$ :}

Effect of dripline arrangement, in treatments (dripline Depth, $D=0$ and dripline Spacing $\mathrm{S} \Rightarrow 0.4-0.5 \mathrm{~m}$ ) VSL gave its core (salt crusts) close to the driplines, the other treatment AL gave its core at the surface in the middle between driplines. Salt concentration in the root zone ranged between $2-62$ and $5-40 \mathrm{dS} . \mathrm{m}^{-1}$ for VSL and AL, respectively. The highest salt concentration of salt crust was $158 \mathrm{dS} \cdot \mathrm{m}^{-1}$ for both treatments, Figs. (2 and 3).

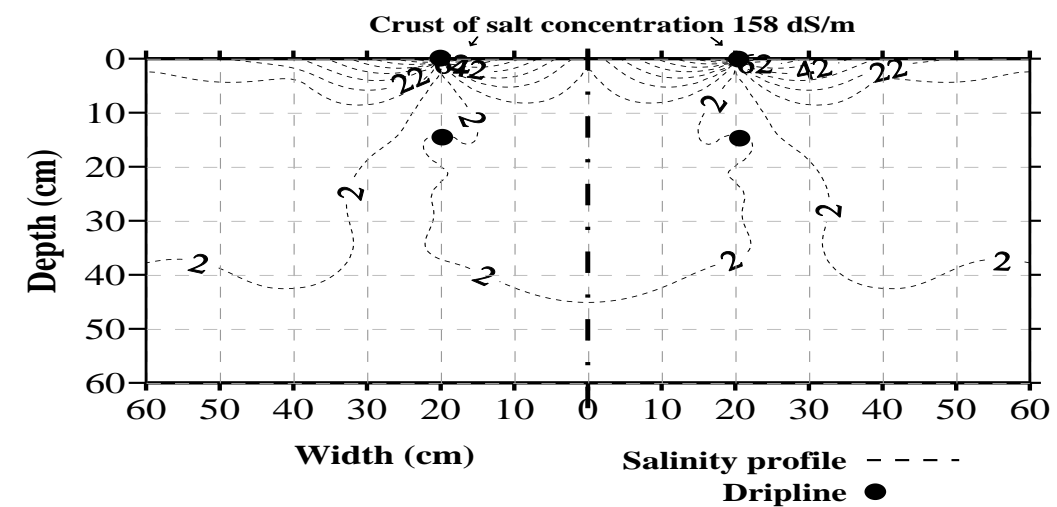

Fig (2): VSL root-zone salt profile $\left(\mathrm{dS} \cdot \mathrm{m}^{-1}\right)$ of $(\mathrm{D}=0$ and $\mathrm{S} \Rightarrow 0.4-0.5 \mathrm{~m})$. In addition, it is clear that in VSL the salt concentration accumulated close to upper driplines and concentrated in the upper layer $(0-10 \mathrm{~cm})$; 
its concentration reached $2-62 \mathrm{dS} . \mathrm{m}^{-1}$; and below this layer, salt concentration reached about $2 \mathrm{dS} \cdot \mathrm{m}^{-1}$. Meanwhile, in AL more salt moved downward to the layer under $10 \mathrm{~cm}$ and its concentration reached to $5 \mathrm{dS} . \mathrm{m}^{-1}$ compared with $2 \mathrm{dSm}^{-1}$ in case of VSL.

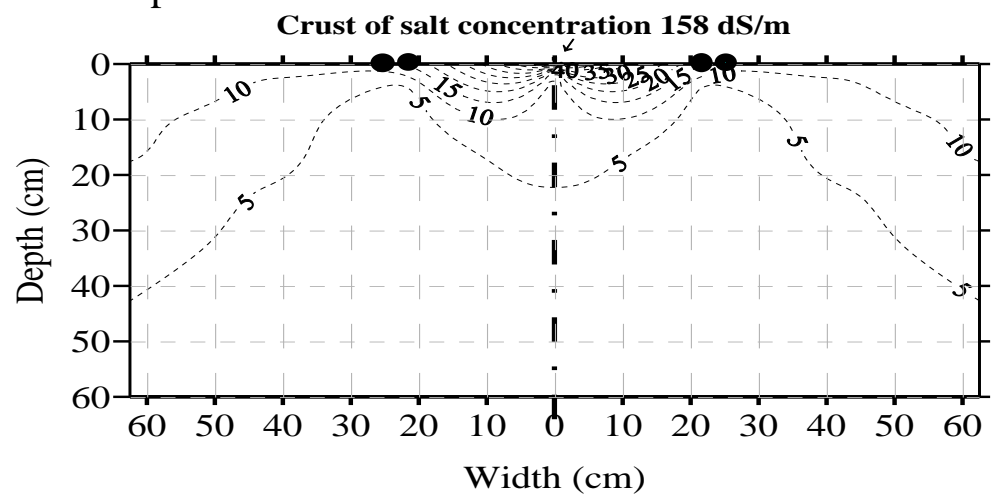

Fig (3): AL root-zone salt profile (dS. $\left.\mathrm{m}^{-1}\right)$ of $(\mathrm{D}=0$ and $\mathrm{S} \Rightarrow 0.4-0.5 \mathrm{~m})$.

From the above-mentioned figures, it is clear that the right part of soil saline distribution of the figures are similar to the left part, then discussion the obtained data will be included one of these parts.

Treatments $(\mathrm{D}=10 \mathrm{~cm}$ and $\mathrm{S} \Rightarrow 0.4-0.5 \mathrm{~m})$, VSL gave the highest salt concentration $\left(8.5 \mathrm{dS} . \mathrm{m}^{-1}\right)$ beside the upper dripline. Meanwhile, AL gave the highest concentration $\left(10 \mathrm{dS} . \mathrm{m}^{-1}\right)$ in the middle between dripline and close to soil surface.

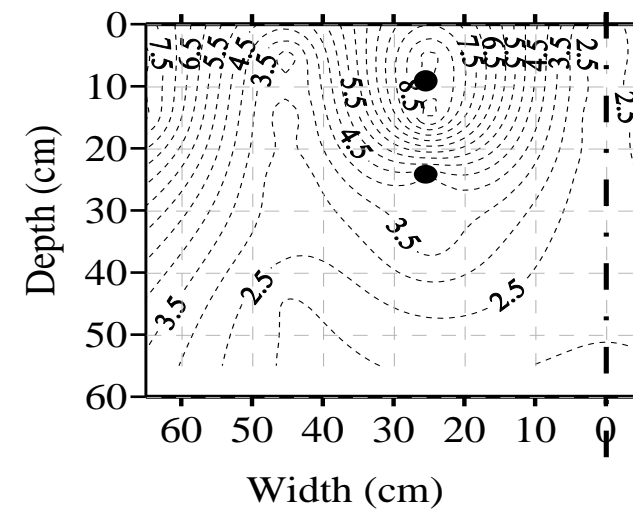

Fig. (4): VLS root zone salt profile $\left(\mathrm{dS} . \mathrm{m}^{-1}\right)$ of $(\mathrm{D}=10 \mathrm{~cm}$ and $\mathrm{S} \Rightarrow 0.4-0.5 \mathrm{~m})$.

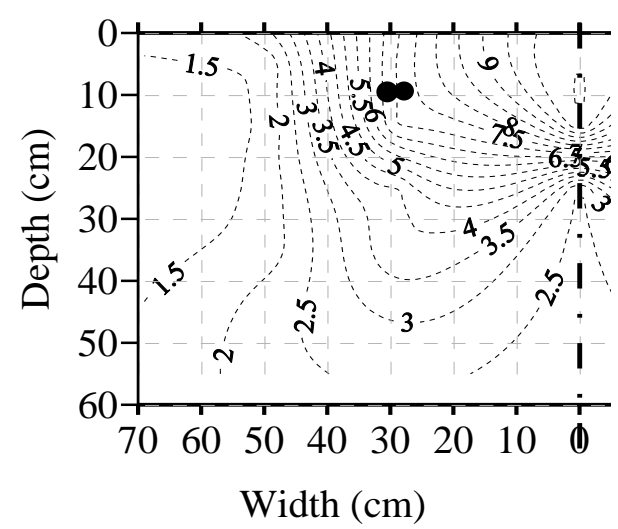

Fig. (5): AL root zone salt profile $\left(\mathrm{dS} . \mathrm{m}^{-1}\right)$ of $(\mathrm{D}=10 \mathrm{~cm}$ and $\mathrm{S} \Rightarrow 0.4-0.5 \mathrm{~m}$ ). 
In treatments $(\mathrm{D}=0$ and $\mathrm{S} \Rightarrow 0.8-1.0 \mathrm{~m})$, same distribution of salt concentration was obtained in VSL and AL, which ranged between $2-52$ dS.m ${ }^{-1}$, Figs. (6 and 7). The highest concentration values were beside driplines in both arrangements. The salt concentrations of surface crust were nearly similar, 131.6 and $129.9 \mathrm{dS} . \mathrm{m}^{-1}$ for VSL and AL, respectively.

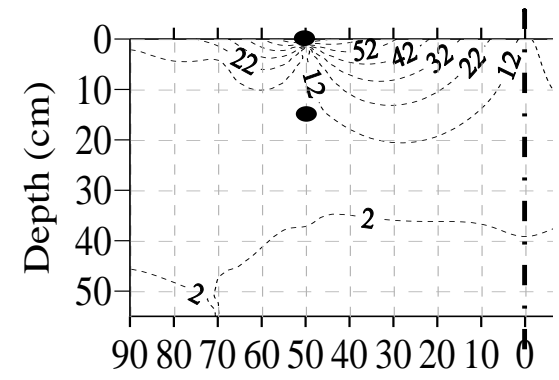

Width $(\mathrm{cm})$

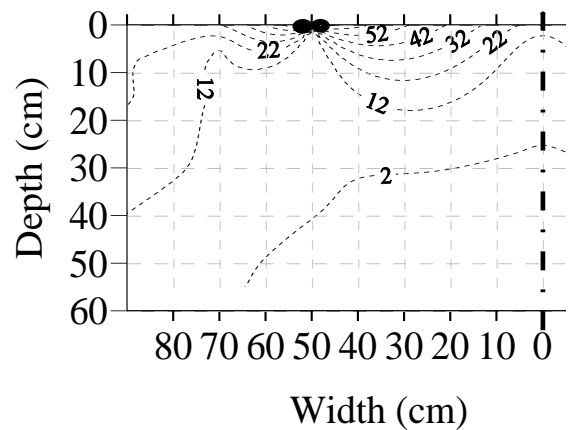

Fig. (7): $A L$ root zone salt profile $\left(\mathrm{dS} . \mathrm{m}^{-1}\right)$ of $(\mathrm{D}=$ 0 and $\mathrm{S} \Rightarrow 0.8-1.0 \mathrm{~m})$.

Fig. (6): VSL root zone salt profile $\left(\mathrm{dS} . \mathrm{m}^{-1}\right)$ of $(\mathrm{D}=$ 0 and $\mathrm{S} \Rightarrow 0.8-1.0 \mathrm{~m})$.

Treatments $(\mathrm{D}=10 \mathrm{~cm}$ and $\mathrm{S} \Rightarrow 0.8-1.0 \mathrm{~m})$, VSL gave salt distributions ranging between 2 and $57 \mathrm{dS} . \mathrm{m}^{-1}$, Fig. (8). The highest concentration value was in the middle between driplines close to soil surface. The salt concentration of crust was $130.8 \mathrm{dS} . \mathrm{m}^{-1}$. In the other AL arrangement salt concentration was between 2 and $8 \mathrm{dS} \cdot \mathrm{m}^{-1}$, Fig. (9). The highest concentration was in the middle between driplines close to soil surface.

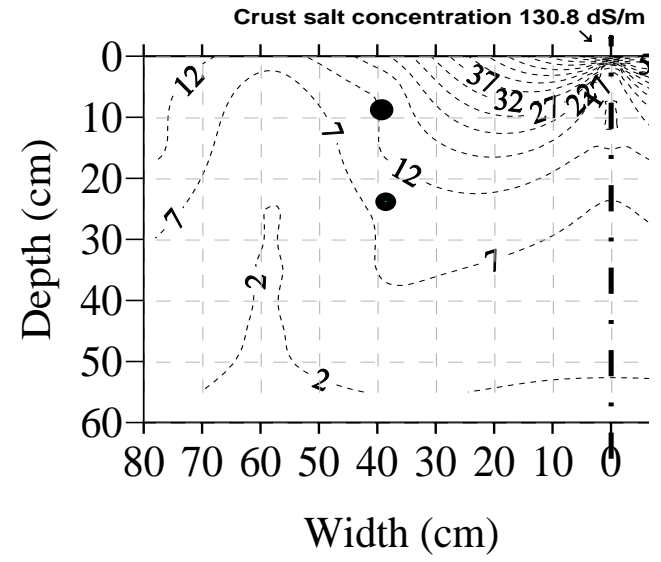

Fig. (8): VSL root zone salt profile $\left(\mathrm{dS} . \mathrm{m}^{-1}\right)$ of $(\mathrm{D}=10 \mathrm{~cm}$ and $\mathrm{S} \Rightarrow 0.8-1.0 \mathrm{~m}$ ).

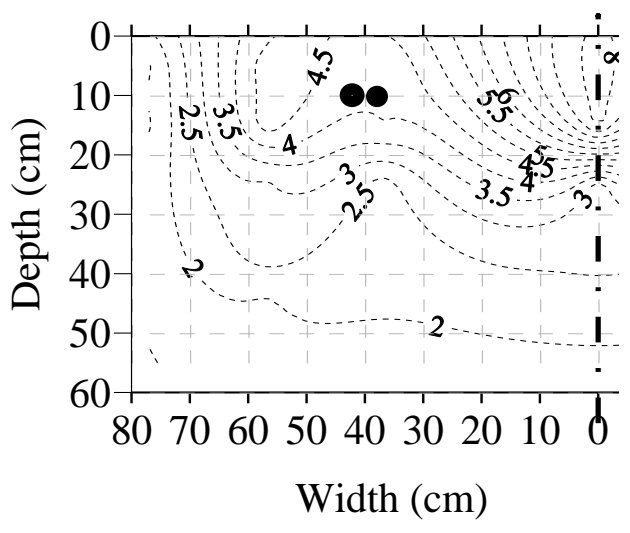

Fig. (9): AL root zone salt profile $\left(\mathrm{dS} \cdot \mathrm{m}^{-1}\right)$ of $(\mathrm{D}=10 \mathrm{~cm}$ and $\mathrm{S} \Rightarrow 0.8-1.0 \mathrm{~m}$ ). 
From the above-mentioned results, it can be concluded that location of the highest value of salt concentration was greatly affected by dripline arrangement, and this may be attributed to soil moisture distribution directly affected by dripline arrangement. Mainly, soil moisture distribution plus evaporation gave the resulted salt distribution for the dripline arrangement. In addition, the accumulated salt played as a factor (osmotic potential) in soil moisture distribution, considered in creating soil salt-distribution. Thus, there was an interaction between soil moisture and salt distributions.

The effect of dripline spacing. The accumulated salt in the root zone of treatments with different spacings gave same distribution, which ranged between $2-62 \mathrm{dS} \cdot \mathrm{m}^{-1}$, Figs. (2 and 6). This means that the difference in dripline spacing did not affect salt distribution. However, high concentrations of the salts crust were beside driplines and recorded 158.2 and $129.9 \mathrm{dS} . \mathrm{m}^{-1}$, for $\mathrm{S} \Rightarrow 0.4-0.5$ and $0.8-1.0 \mathrm{~m}$, respectively. This may be attributed to that moisture content of small dripline spacing was higher than of wider spacing, then evaporation of narrow dripline spacing was higher than of wider spacing. This led to surface salt crust accumulation higher in narrow dripline spacing than that in wider spacing.

Interaction between the dripline spacing and other treatments (dripline arrangement and depth) indicates effect of dripline spacing on soil salt distribution. Likewise, decreasing dripline spacing range from $0.8-1.0$ to $0.4-0.5 \mathrm{~m}$ under $10 \mathrm{~cm}$ dripline depth and with VSL arrangement clearly decreased accumulated soil salt from $2-57 \mathrm{dS} . \mathrm{m}^{-1}$ to $2-8.5 \mathrm{dS} . \mathrm{m}^{-1}$ and differed also in surface salt, Figs. (4 and 8).

In the other dripline arrangement AL with surface dripline, the difference was not only in magnitude of accumulated salt in the root zone, which changed from $\left(5-40 \mathrm{dS} \cdot \mathrm{m}^{-1}\right)$ to $\left(2-52 \mathrm{dS} . \mathrm{m}^{-1}\right)$ for dripline spacing range $0.4-0.5$ and $0.8-1.0 \mathrm{~m}$, respectively, but also changed location of highest concentration, Figs. (3 and 7). It is clear that the small dripline spacing decreased the surface concentration, but in the same time led to the movement of salt in the whole root zone.

The effect of driplines depths. All treatments showed that increasing depth of driplines decreased salt concentration in the root zone because 
of decreasing the evaporation potential, which resulted from decreasing soil moisture at surface. Under VSL arrangement, $S \Rightarrow 0.4-0.5 \mathrm{~m}$ with surface driplines depth gave salt concentration $2-62 \mathrm{dS} . \mathrm{m}^{-1}$, Fig. (2) as compared to $2-8.5 \mathrm{dS} . \mathrm{m}^{-1}$ for $10 \mathrm{~cm}$ driplines depth, Fig. (4). In addition, salt crusts appeared on soil surface $\left(158.2 \mathrm{dS} . \mathrm{m}^{-1}\right)$ beside driplines and was absent in subsurface case.

In the other arrangement $\mathrm{AL}$, with surface driplines salt concentration reached to $5-40 \mathrm{dS} \cdot \mathrm{m}^{-1}$, Fig. (3) as compared to $2-10 \mathrm{dS} \cdot \mathrm{m}^{-1}$ for $10 \mathrm{~cm}$ driplines depth, Fig. (5). There were salt crusts of $\left(91.3 \mathrm{dS} . \mathrm{m}^{-1}\right)$ in the middle at surface between driplines in surface dripline but was absent in subsurface case.

Also, dripline depth effected the location of salt cone, while there were two accumulated salt cones around driplines in surface driplines, Fig. (8). Only one salt cone accumulated in the middle between driplines in the case of 10 cm driplines depth, Fig. (6). These results are in agreement with Keller and Karmeli (1975), Bakeer, 1996, Aboamera (1999), Keller and Bliesner (1990), and El-Tantawy (2000).

Treatments with underneath PE foil ( $\left.\mathbf{E}_{2}\right)$, Figs. (10 and 11) gave same behavior under AL, arrangement but under VSL arrangement the location of the highest concentrated salt moved from the middle at the surface to

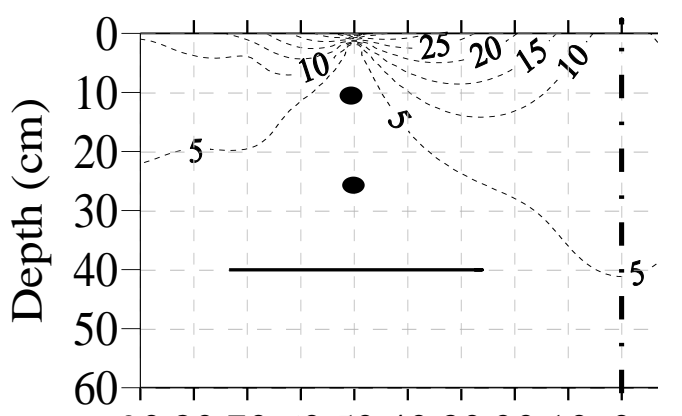

9080706050403020100

Width $(\mathrm{cm})$

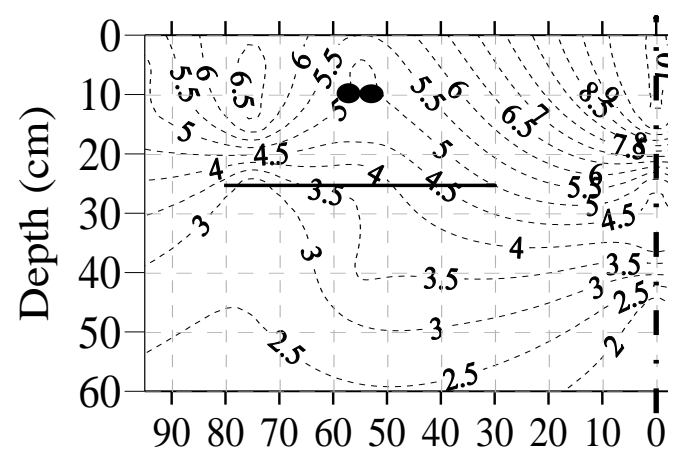

Width $(\mathrm{cm})$

directly above driplines.

Fig. (10): VSL root zone salt profile $\left(\mathrm{dS} . \mathrm{m}^{-1}\right)$ of $(\mathrm{D}=10 \mathrm{~cm}$ and $\mathrm{S} \Rightarrow 0.9-1.2 \mathrm{~m}$ ) Fig. (11): AL root zone salt profile with underneath PE foil. $\left(\mathrm{dS} . \mathrm{m}^{-1}\right)$ of $(\mathrm{D}=10 \mathrm{~cm}$ 


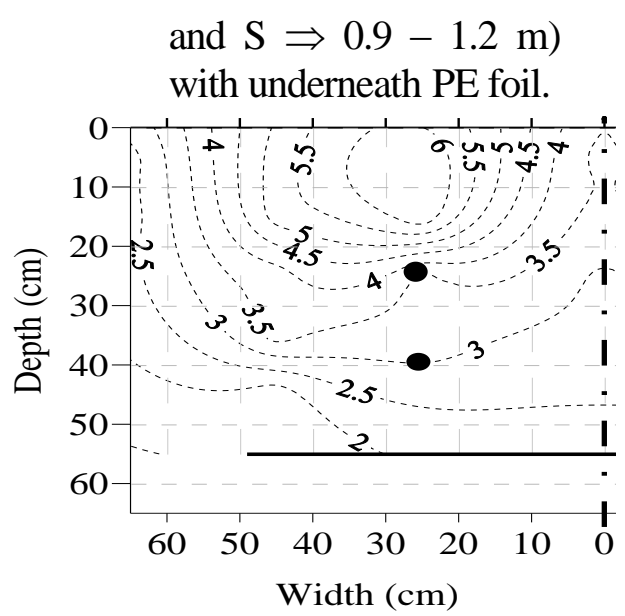

Fig. (12): VSL root zone salt profile $\left(\mathrm{dS} . \mathrm{m}^{-1}\right)$ of $(\mathrm{D}=25 \mathrm{~cm}$ and $S \Rightarrow 0.3-0.6 \mathrm{~m}$ )

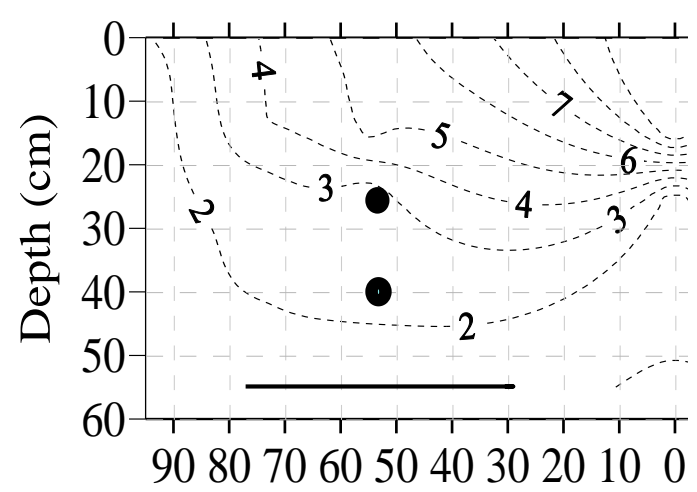

Width $(\mathrm{cm})$

with underneath PE foil.

Fig. (14): VSL root zone salt profile $\left(\mathrm{dS} \cdot \mathrm{m}^{-1}\right)$ of $(\mathrm{D}=25 \mathrm{~cm}$ and $\mathrm{S} \Rightarrow 0.9-1.2 \mathrm{~m}$ ) with underneath PE foil.

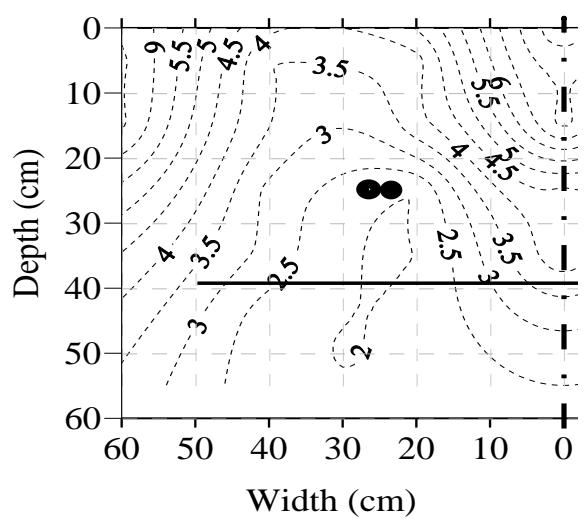

Fig. (13): $\mathrm{AL}$ root zone salt profile $\left(\mathrm{dS} . \mathrm{m}^{-1}\right)$ of $(\mathrm{D}=25 \mathrm{~cm}$ and $S \Rightarrow 0.3-0.6 \mathrm{~m}$ ) with

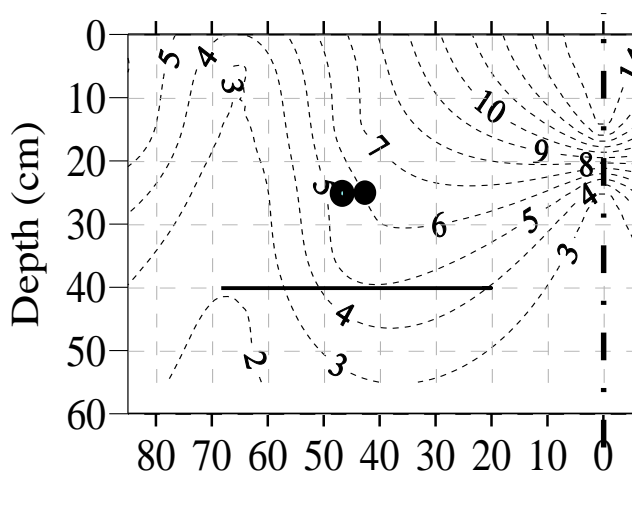

Widht $(\mathrm{cm})$

underneath PE foil.

Fig. (15): AL root zone salt profile $\left(\mathrm{dS} \cdot \mathrm{m}^{-1}\right)$ of $(\mathrm{D}=25 \mathrm{~cm}$ and $\mathrm{S} \Rightarrow 0.9-1.2 \mathrm{~m}$ ) with underneath $\mathrm{PE}$ foil.

The effect of dripline spacing. Accumulated salt concentration in VSL decreased with increasing dripline spacing from $0.3-0.6$ to $0.9-1.2 \mathrm{~m}$ at $\mathrm{D}=10 \mathrm{~cm}$. This may be attributed to two reasons: the first that evaporation decreased with dripline spacing. The second was that underneath PE foil, in the narrow spacing, lead to more water percolation, then moisture loss by evaporation was more than in the wider spacing. 
The effect of driplines depths. variation in driplines depth gave high effect in accumulated salt concentration, same as without underneath foil, where increasing dripline depths decreased accumulated salt as shown with $\mathrm{D}=10 \mathrm{~cm}$, Figs. (10 and 16) as compared with $\mathrm{D}=25 \mathrm{~cm}$, Figs. (12 and 14), also when comparing between surface depth $\mathrm{D}=0$, Fig. (17) and that of $\mathrm{D}=10 \mathrm{~cm}$, Fig. (13).

On the other hand, in arrangement $\mathrm{AL}$ and $\mathrm{S} \Rightarrow 0.9-1.2 \mathrm{~m}$, increasing driplines depth from $10 \mathrm{~cm}$, (Fig., 11) to $25 \mathrm{~cm}$, (Fig., 15) did not change the concentrated salt of root zone. This may be attributed to that was initially low soil moisture in the sallow depth.

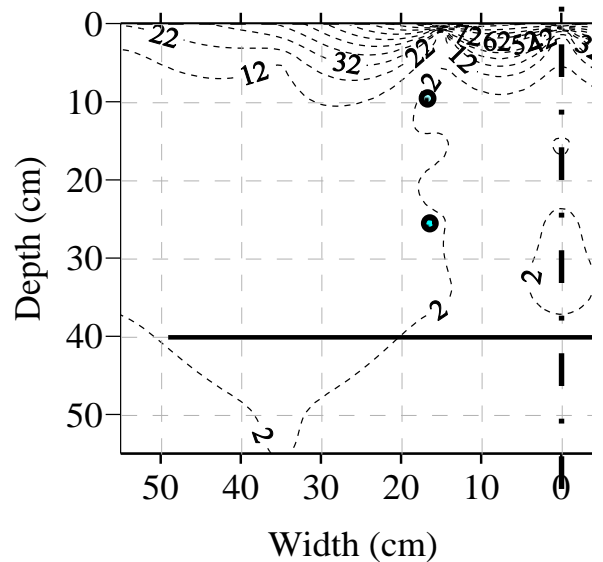

Fig. (16): VSL root zone salt profile $\left(\mathrm{dS} . \mathrm{m}^{-1}\right)$ of $(\mathrm{D}=10 \mathrm{~cm}$ and $\mathrm{S} \Rightarrow 0.3-0.6 \mathrm{~m})$ with underneath PE foil.

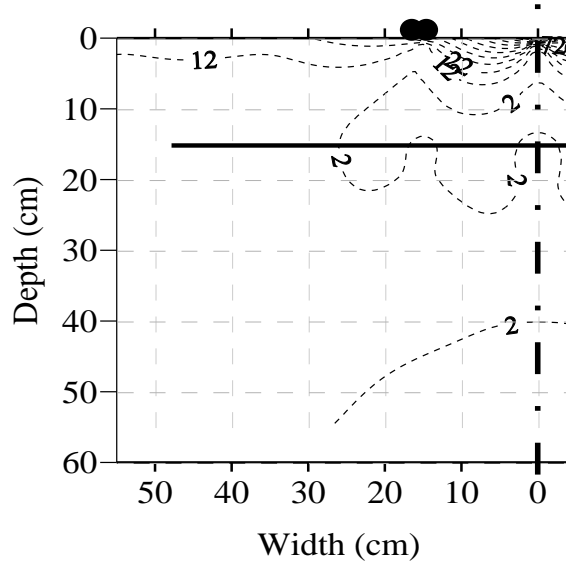

Fig. (17): AL root zone salt profile $\left(\mathrm{dS} . \mathrm{m}^{-1}\right)$ of $(\mathrm{D}=0$ and $\mathrm{S}$ $\Rightarrow 0.3-0.6 \mathrm{~m}$ ) with underneath PE foil.

\section{Onion yield:}

The significance of the main effects of factors and their interactions on onion yield were obtained. It is clear that the main effect of dripline spacing (S) is highly significant in both without and with underneath PE foil. However, the significance of interaction effects varied according to the presence of underneath PE foil. In case of without underneath foil, the interaction effects of $\mathrm{A}$ (driplines arrangement) $\times \mathrm{D}$ (dripline depth) and $\mathrm{A} \times \mathrm{S}$ are significant at $5 \%$ level. However, $\mathrm{D} \times \mathrm{S}$ is only highly significant. In case of underneath foil, significant effect is obtained in 
case of $\mathrm{A} \times \mathrm{D}$ interaction in contrast with other interaction effects, are non-significant.

Effect of the treatments without underneath PE foil. Table (2) shows the main effect of dripline depth on onion yield and WUE regardless of dripline spacing and arrangement. It is clear that the average onion yield increased from 1.3 to $1.7 \mathrm{t} /$ fed when the driplines depth was changed from the surface to the $10 \mathrm{~cm}$. These results are in agreement with Barth (1995), Bakeer (1996), and Awady et al. (2003). Also, the average WUE increased from 0.25 to $0.39 \mathrm{~kg} / \mathrm{m}^{3}$ when the driplines depth changed from the surface to $10 \mathrm{~cm}$ depth.

Table (2): Onion yield and WUE as affected by all factors under investigation and their interactions.

\begin{tabular}{|c|c|c|c|c|c|}
\hline $\begin{array}{l}\text { Underneath } \\
\text { foil }\end{array}$ & $\begin{array}{c}\text { Dripline } \\
\text { arrangement } \\
\text { state } \\
\end{array}$ & \begin{tabular}{|c|} 
Dripline \\
depth \\
$(\mathrm{cm})$ \\
\end{tabular} & $\begin{array}{l}\text { Dripline } \\
\text { spacing } \\
\text { range }(\mathrm{m})\end{array}$ & $\begin{array}{c}\text { Yield } \\
\text { (ton/fed) }\end{array}$ & $\begin{array}{c}\text { WUE } \\
\left(\mathrm{kg} / \mathrm{m}^{3}\right)\end{array}$ \\
\hline \multirow{10}{*}{ Without } & \multirow{5}{*}{ VSL } & \multirow{2}{*}{0} & $0.4-0.6$ & 1.67 & 0.26 \\
\hline & & & $0.8-1.0$ & 0.82 & 0.25 \\
\hline & & \multirow{3}{*}{10} & $0.4-0.6$ & 2.42 & 0.37 \\
\hline & & & $0.6-0.8$ & 1.60 & 0.40 \\
\hline & & & $0.8-1.0$ & 1.65 & 0.50 \\
\hline & \multirow{5}{*}{$\mathrm{AL}$} & \multirow{2}{*}{0} & $0.4-0.6$ & 2.21 & 0.34 \\
\hline & & & $0.8-1.0$ & 0.52 & 0.16 \\
\hline & & \multirow{3}{*}{10} & $0.4-0.6$ & 1.81 & 0.28 \\
\hline & & & $0.6-0.8$ & 1.76 & 0.44 \\
\hline & & & $0.8-1.0$ & 1.14 & 0.35 \\
\hline \multirow{8}{*}{ With } & \multirow{4}{*}{ VSL } & \multirow{2}{*}{10} & $0.3-0.6$ & 1.90 & 0.29 \\
\hline & & & $0.9-1.2$ & 0.82 & 0.21 \\
\hline & & \multirow{2}{*}{25} & $0.3-0.6$ & 2.92 & 0.37 \\
\hline & & & $0.9-1.2$ & 1.23 & 0.44 \\
\hline & \multirow{4}{*}{$\mathrm{AL}$} & \multirow{2}{*}{10} & $0.3-0.6$ & 2.70 & 0.41 \\
\hline & & & $0.9-1.2$ & 1.51 & 0.39 \\
\hline & & \multirow{2}{*}{25} & $0.3-0.6$ & 2.27 & 0.29 \\
\hline & & & $0.9-1.2$ & 1.08 & 0.39 \\
\hline
\end{tabular}


The main dripline spacing effect on average onion yields were $1.03,1.68$, and $2.03 \mathrm{t} / \mathrm{fed}$ at spacings of $0.8-1.0,0.6-0.8$, and $0.4-0.6 \mathrm{~m}$, respectively. These results are in harmony with El-Gindy et al. (2001). WUE was also affected by dripline spacing and its values were $0.31,0.32$, and $0.42 \mathrm{~kg} / \mathrm{m}^{3}$ for ranges of $0.4-0.6,0.8-1.0$, and $0.6-0.8 \mathrm{~m}$, respectively. Obviously, onion yield increased by decreasing driplines spacing but the optimum WUE was at $0.6-0.8 \mathrm{~m}$ dripline spacing.

It is worth to mention that the best onion yield $(2.42 \mathrm{t} / \mathrm{fed})$ was obtained from $10 \mathrm{~cm}$ dripline depth and $0.4-0.5 \mathrm{~m}$ dripline spacing range under VSL arrangement, which had low concentration and homogeneous salt distribution, Fig (4). However, the lowest onion yield (0.52 t/fed) was obtained from surface dripline and $0.8-1.0 \mathrm{~m}$ dripline spacing under AL arrangement, which had high salt concentration near root zone, Fig. (7).

Onion yield under treatments with underneath PE foil, Table (2) shows the onion yield as affected by factors under investigation and their interactions. Average onion yields were 1.1, and $2.4 \mathrm{t} /$ fed at dripline spacings of $0.9-1.2$, and $0.3-0.6 \mathrm{~m}$, respectively. These results are in agreement with El-Gindy et al. (2001). WUE was slightly affected by dripline spacing ranges and its values were 0.35 , and $0.36 \mathrm{~kg} / \mathrm{m}^{3}$ for dripline spacing ranges of $0.3-0.6$, and $0.9-1.2 \mathrm{~m}$, respectively, Fig. (21). Obviously, onion yield increased by decreasing dripline spacing range.

The interactions of $(A \times D \times S),(A \times S)$, and $(D \times S)$ were non significant with underneath $\mathrm{PE}$ foil. This means that all of these factors affect independently on onion yield.

Onion yield and water use efficiency (WUE) was affected by (depth $\mathrm{x}$ arrangement) interaction. Obviously, increasing dripline depth from 10 to $25 \mathrm{~cm}$ increased onion yield and WUE in VSL driplines arrangement. However, yield and WUE took an inverse trend with AL arrangement, where they decreased with increasing dripline depth, because the soil moisture limitation due to increasing dripline depth to $25 \mathrm{~cm}$ was the reason of this case. These results are in agreement with Cote et al. (2003). 
In addition, the efficiency of VSL arrangement was more pronounced in case of $25 \mathrm{~cm}$ depth and dripline spacing $0.3-0.6 \mathrm{~m}$, which gave onion yield of $2.9 \mathrm{t} / \mathrm{fed}$.

The highest onion yield with PE foil under VSL arrangement was (2.9 $\mathrm{t} / \mathrm{fed}$ ) obtained from $25 \mathrm{~cm}$ dripline depth and $0.3-0.6 \mathrm{~m}$ dripline spacing, which had uniformed low concentration soil salt, Fig. (12). However, the lowest one $(0.82 \mathrm{t} / \mathrm{fed})$ was obtained from $10 \mathrm{~cm}$ dripline depth and 0.9 $1.2 \mathrm{~m}$ dripline spacing, due to the concentrated salt and located at the surface near the onion root, Fig. (10), although it has soil moisture higher than that in case of c. Increasing salt concentration was more pronounced as limiting factor for yield than soil moisture, and this affected yield because onion is less tolerant to soil salinity. These are in agreement with Ayers and Westcott (1985).

\section{SUMMARY AND CONCLUSIONS}

- Concerning, AL arrangement, (2.9 t/fed) was obtained under surface dripline depth and dripline spacing range $0.3-0.6 \mathrm{~m}$, which had (186.6 dSm-1) concentrated salt in the middle between the driplines near the surface and far from the onion root zone, while the local root zone soil salt concentration was $12 \mathrm{dSm}-1$, Fig. (17). On the other hand, $25 \mathrm{~cm}$ dripline depth and $0.9-1.2 \mathrm{~m}$ dripline spacing gave $(1.08 \mathrm{t} / \mathrm{fed})$ onion yield inspite of low soil salinity Fig., (15). Consequently, the soil moisture limitation due to increasing dripline depth to $25 \mathrm{~cm}$ was the reason of this case.

- Salt crust was obtained when the moisture at soil surface was more than $10 \%$ volumetric percentage under studied conditions.

- Best WUE for onion reached $0.5 \mathrm{~kg} / \mathrm{m}^{3}$ in the case of VSL with 0.8 $1.0 \mathrm{~m}$ spacing and $10 \mathrm{~cm}$ depth, under without underneath foil.

- The highest onion yield under VSL arrangement (2.9 t/fed) was obtained from $25 \mathrm{~cm}$ dripline depth and $0.3-0.6 \mathrm{~m}$ dripline spacing with underneath PE foil, which had uniformity low salt concentration without high salt concentrated points.

\section{REFERENCES}

Aboamera, M. A. (1999). Performance of subsurface drip irrigation in sandy soil under different lateral depths. Misr J. Ag. Eng., 16(3): $612-624$. 
Awady, M. N., M. F. Abd El-Salam, M. M. El-Nawawy, and M. A. ElFarrah (2003). Surface and subsurface irrigations effects on spinach and sorghum. "Ag Eng Role in Reducing Losses and Maximizing Prod. The $11^{\text {th }}$ Ann. Conf. Misr Soc. Agric. Ang., 15-16 Oct., 20 (4): $118-130$.

Ayer, R. S., and D. W. Westcott (1985). Water quality for agriculture. Food and Agricultural Organization of the United Nations. Irrigation and Drainage Paper 29.

Bakeer, G. A. (1996). The effect of applying drip irrigation system under certain environmental resources on soil productivity deterioration at North Sinai. Misr J. Agric. Eng., 13(2): 305 - 325.

Barth H. K. (1995). Resource conservation and preservation through a new subsurface irrigation system. Proc. $5^{\text {th }}$ I. Microirrig. Cong. April 2-6, Orlando, Florida. ASAE, 2950 Niles Rd., St. Joseph, MI 49085-9659: 168 - 174.

Blake, G. R. and K. H. Hartge (1986). Bulk density. Methods of soil analysis, Part (1). Physical and mineralogical methods-agronomy monograph No. 9 ( $2^{\text {nd }}$ Edition). Am. Soc. of Agron.-Soil Sci. Soc. Am., 677 South Segoe Road, Madison, WI 53711, USA: 363 - 382.

Burman R. D., P. R. Nixon, J. L. Wright and W. O. Pruitt, (1983). Water requirements. Ch. 6 In: M. E. Jensen (Ed.): Design and operation of farm irrigation systems. ASAE Mono \# 3:189-225.

Cote, C. M., K. L. Bristow, P. B. Charlesworth, F. J. Cook, and P. J. Thorburn (2003). Analysis of soil wetting and solute transport in subsurface trickle irrigation. Irri. Sci. (2003) 22: 143-156 p.

El-Gindy, A. M., H. N. Abdel-Mageed, M. A. El-Adl, and E. M. K. Mohamed (2001). Management of pressurized irrigated faba bean in sandy soils. Misr J. Ag. Eng., 18 (1): 29 - 44.

El-Roby, M. M. (1991). Statistical analysis methods, Biological experiments, Faculty of Agriculture, Alex. Univ. (Arabic language): $66-77$.

El-Tantawy, M. T. (2000). Surface and subsurface drip irrigation effects on soil and tomato yield. $8^{\text {th }}$ Conf. Misr Soc. Agric. Eng., 25-26 Oct: $154-166$.

Gee, G. W. and J. W. Bauder (1986). Particle-size Analysis. Methods of soil analysis, Part (1). Phys and Mineral Methods-Agron 
monograph no. 9 ( $2^{\text {nd }}$ Edi). Am. Soc. Agron-Soil Sci. Am; 677 South Segoe Road, Madison, WI 53711, USA: 383 - 409.

Ismail, S. M., T. K. Zien El-Abedin, T. K. Wassif, and M. N. El-Nesr (2006). Wetting pattern simulation of surface and subsurface drip irrigation system, II-Model, validation and analysis. The $14^{\text {th }}$ Ann. Conf. Misr Soc. Agr. Eng. "New Trends in Agric Eng." 2 Nov. 2006. Misr J. Ag. Eng., 23 (4): 1035 - 1057.

Keller, J. and D. Karmeli, (1975). Trickle irrigation design, RainBird Sprink. Co., Glindora, Cal.: 133.

Keller, J., and R. D. Bliesner (1990). Sprinkle and trickle irrigation. Chapman and Hall Pub. 115, NY 1003. 522 - 551.

Oron, G., Y. DeMalach, L. Gillerman, and I. David. (1995). Pear response to saline water application under subsurface drip irrigation. In Proc of the $5^{\text {th }}$ I. Microirr. Cong. April $2-6$, Orlando, Florida. ASAE, 2950 Niles Rd., St. Joseph, MI 49085-9659: 97 - 103.

Peech, M. (1965). Hydrogen-ion activity. Methods of soil analysis, part (2), Chem and microb properties Handbook, Eds. (Black, C. A., D. D. Evans, L. E. Ensminger, J. L. White, F. E. Clark, and R. C. Dinauer). Am. Soc. of Agron, Inc., Publ Madison, Wisc, USA, Agron. No. (9): 914 - 925.

Richard, L. A. (1965). Determination of the properties of saline and alkali soils. Diagnosis and improvement of saline and alkali soils. USDA Ag. Hndbk. No. 60: 7 - 18.

$$
\begin{aligned}
& \text { الملخص العربي }
\end{aligned}
$$

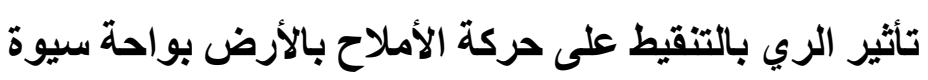

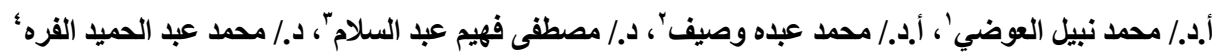

$$
\begin{aligned}
& \text { أجري هذا البحث بمحطة مركز بحوث الصـر اء بو احة سيوة - محافظة مطروح، بهدف در اسـة }
\end{aligned}
$$

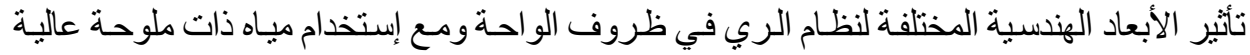

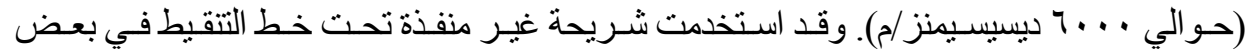

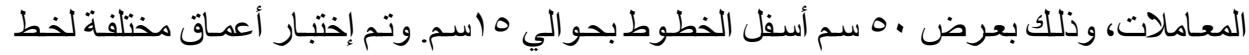

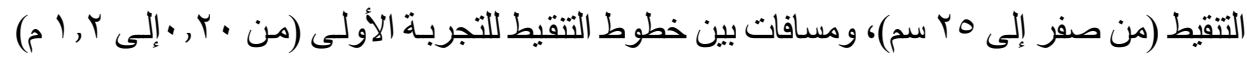

$$
\begin{aligned}
& \text { وللتجربة الثانية ( • ع, • إلى • , ( م). }
\end{aligned}
$$

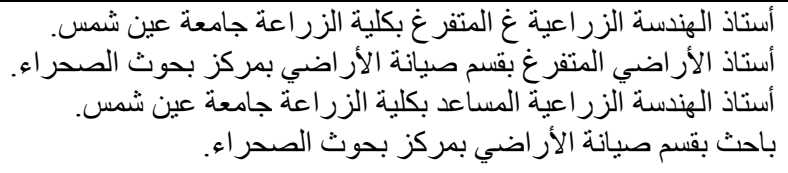

The $17^{\text {th }}$. Annual Conference of the Misr Society of Ag. Eng., 28 October, $2010 \quad-1809$ - 
و أخذ توزيع الرطوبة في قطاع التربة على عمق واحد أوعمقين وذلك بوضع خطي تثقيط متلازمين (خ م) أو

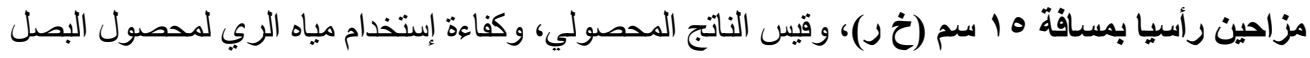

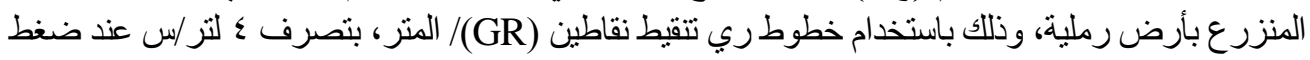
و واحد جوى. مون.

وقد توصلت الدر اسة إلى النتائج الآتية:

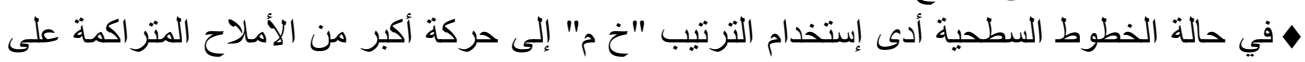

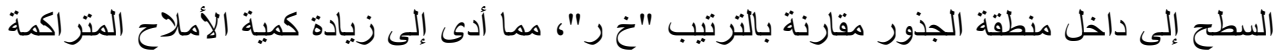

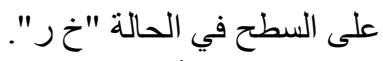

• التراكم الملحي أعلى الخطوط تحت السطحية كان ذا تركيز أعلى من المنطقة الوسطى بين خطوط

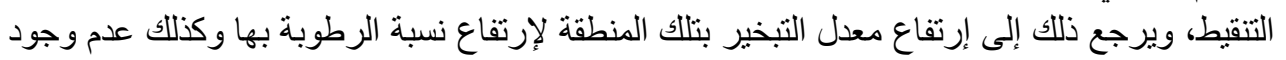

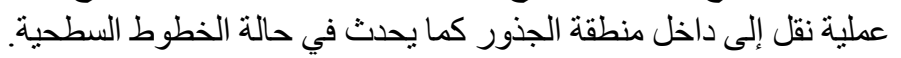

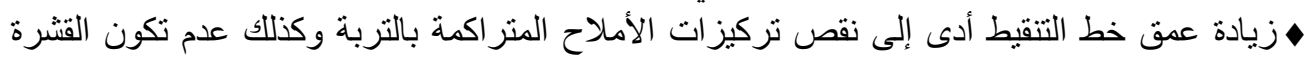

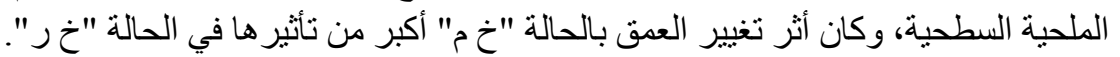

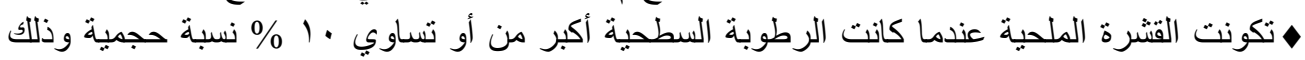

$$
\text { بظروف الدر اسة. }
$$

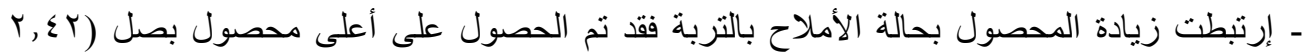

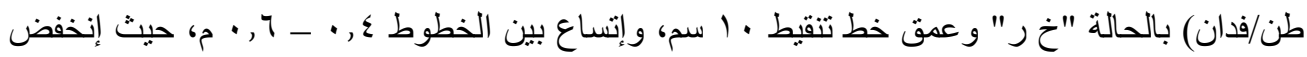

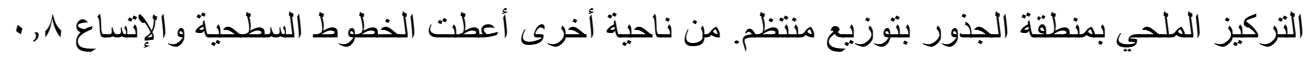

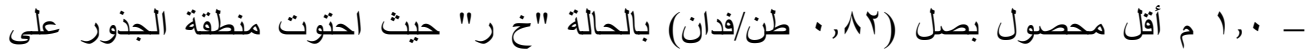

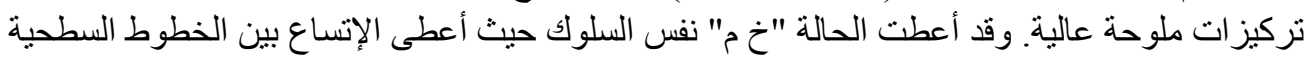

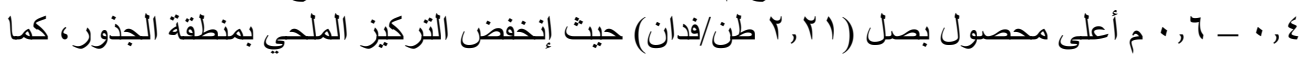

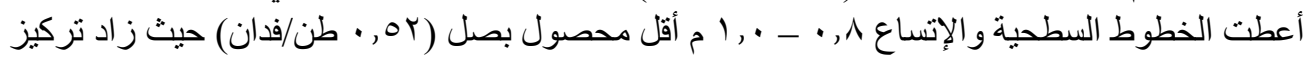
الأملاح بمنطقة الجذور.

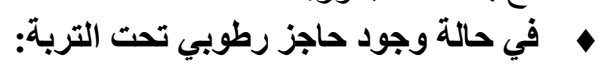

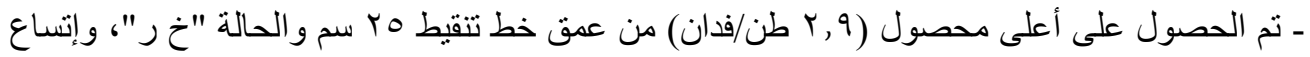

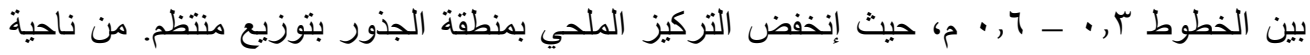

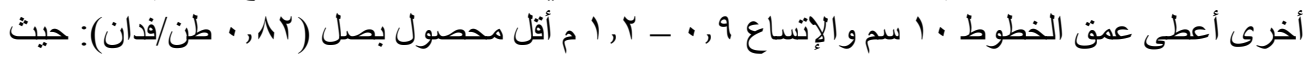

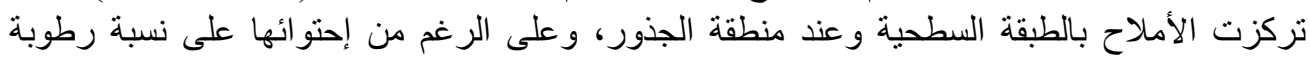

أرضية أعلى من المعاملة التي أعطت أعلى محصول، لكن التركيز الملحي في هذه الحالة كان غالباً.

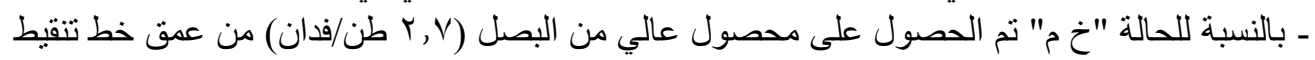

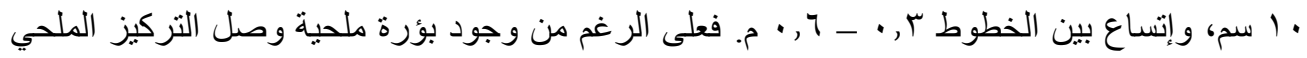

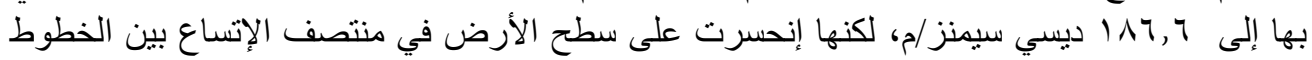

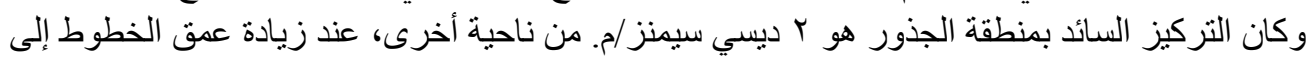

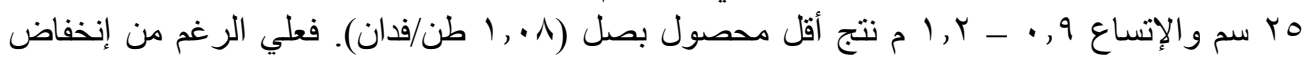

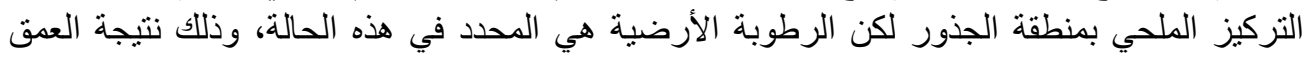
الكبير لخط التنقيط.

The $17^{\text {th }}$. Annual Conference of the Misr Society of Ag. Eng., 28 October, $2010 \quad-1810-$ 